\title{
KAJIAN EFISIENSI PENGGUNAAN FAKTOR-FAKTOR PRODUKSI PADA USAHATANI BAWANG PUTIH DI KABUPATEN KARANGANYAR
}

\author{
Catur Rini Sulistyaningsih ${ }^{1)}$ \\ 1)Jurusan Agribisnis Fakultas Pertanian Universitas Veteran Bangun Nusantara \\ Corresponding Author. caturrinisulistyaningsih@gmail.com
}

\begin{abstract}
ABSTRAK
Penelitian ini bertujuan untuk mengkaji besarnya biaya, penerimaan dan keuntungan usahatani bawang putih, untuk mengkaji pengaruh faktor-faktor produksi terhadap produksi bawang putih dan untuk mengkaji tingkat efisiensi ekonomi penggunaan faktor-faktor produksi pada usahatani bawang putih. Faktor-faktor produksi yang diteliti meliputi: Iuas lahan, benih kemudian pupuk kandang, pupuk Urea, pupuk SP36 dan pupuk $\mathrm{KCl}$. Untuk mengetahui hubungan anatara faktor produksi dengan produksi bawang putih digunakan model fungsi produksi Cobb-Douglas dan dianalisis dengan regresi linear ganda. Faktor-faktor produksi yang meliputi luas lahan dan pupuk kandang berpengaruh nyata terhadap produksi bawang putih. Sedangkan untuk faktor produksi seperti tenaga kerja, benih, pupuk Urea, pupuk SP36 dan pupul $\mathrm{KCl}$ tidak berpengaruh nyata terhadap produksi bawang putih. Adapun faktor produksi yang paling berpengaruh diantara faktor produksi lainnya adalah luas lahan, benih kemudian pupuk kandang, pupuk Urea, pupuk SP36 dan pupuk $\mathrm{KCl}$ sudah tidak efisien. Dengan demikian di dalam kombinasi faktor produksi menunjukkan alokasi faktor-faktor produksi pada usahatani bawang putih belum mencapai optimal.
\end{abstract}

Kata Kunci: faktor produksi, usahatani, bawang putih.

\section{PENDAHULUAN}

Pembangunan pertanian tetap mempunyai peranan penting dalam pembangunan jangka panjang ke dua. Sumbangan sektor pertanian, masih menyerap angkatan kerja terbesar, penghasil devisa, serta pendukung proses industrialisasi, khususnya dalam penyediaan bahan baku dan bahan mentah (Wandyatmoko, J. 1996).

Kebijaksanaan pembangunan pertanian di Indonesia senantiasa didasarkan pada amanat yang telah dituliskan dalam Garis Besar Haluan Negara. Dalam Pembangunan Lima Tahun (Pelita) IV, pembangunan pertanian di Indonesia diarahkan untuk memenuhi tujua yang ingin diapai yaitu untuk mencapai kesejahteraan masyarakat pertanian yang lebih merata. Tujuan pembangunan pertanian dapat dilakukan dengan cara meningkatka produksi, produktivitas tenaga kerja, tanah dan modal (Soekarwati, 1993). 
Lampu hijau bagi pengembangan budidaya hortikultura nasional telah dinyalakan. Budidaya sayur-mayur, kini tampil sebagi usahatanimasyarakat yang mendapat prioritas (Entang, S., 1989). Hortikultura mengandung nilai kesehatan, karena penting untuk memenuhi kebutuhan jasmani. Hal ini dikarenakan hasilnya banyak mengandung vitamin dan mineral yang berfungsi sebagai pengatur pelindung daripada jaringan tubuh, serta penting pula sebagai sumber daripada protein nabati (Sunaryo, H., 1990)

Pusat penelitian dan pengembangan hortikultura pada periode 1989-1994 menetapkan pengembangan bawang putih sebagai prioritas utama bersama-sama komoditas sayuran bernilai ekonomi tinggi lainnya seperti cabai, bawang merah, tomat, kentang, kubis-kubisan dan kacang-kacangan (Rukmana, R., 1995). Dipandang dari segi ekonomi meski budidaya bawang putih relatif tinggi hasil panen per hektar dapat mencapai jutaan rupiah tidak mengherankan kalau bawang putih dikategorikan sebagai komoditi primadona masa kini atau emas putih (Santoso, H.B., 1988)

Komoditas bawang putih berperan cukup besar terhadap peningkatan gizi masyarakat peningkatan pendapatan petani perluasan tenaga kerja peningkatan pendapatan negara dan memacu ekspor (Rukmana, R., 1995). Banyaknya manfaat dan besarnya peranan bawang putih dalam menunjang kehidupan manusia maka pengembangan bawang putih menjadi penting untuk memenuhi kebutuhan manusia yang semakin besar

Menurut Samadi B. (2000) serapan pasar bawang putih dapat dilihat dari banyaknya manfaat yang dapat digunakan oleh masyarakat dan meningkatnya jumlah penduduk semakin besar manfaat yang dapat diambil dari bawang putih maka makin besar pula. Permintaan bawang putih begitu pula jumlah penduduk yang semakin bertambah akan meningkat pula kebutuhan terhadap bawang putih. Sentra produksi bawang putih di dalam negeri adalah Provinsi Jawa Tengah pada umumnya bawang putih diusahakan di lahan kering diatas 800 meter diatas permukaan laut, oleh karena itu hanya beberapa daerah di Indonesia terutama daerah pegunungan saja yang dapat diusahakan tanaman bawang putih.

\subsection{Latar Belakang}

Di Kabupaten Karanganyar dapat 4 daerah pengembangan komoditas bawang putih yaitu Kecamatan Jatiyoso, Tawangmangu, Ngargoyoso, dan Jenawi upaya peningkatan produksi di Kabupaten Karanganyar ini tergantung dari sentrasentra produksi Bawang Putih yang ada agar terus meningkat dan adanya upaya pengelolaan yang baik pula persoalan adalah sumber daya atau faktor produksi yang terbatas seperti lahan dan modal yang harus diusahakan seefisien mungkin penggunaannya sehingga produktivitas yang diharapkan dapat tercapai atau terus meningkat

\subsection{Tujuan Penelitian}


Untuk penignkatan produksi dalam mengimbangi permintaan konsumen yang terus menignkat, yang menjadi persoalan pokok yang selalu melekat adalah aspek ekonomi. Persoalan ekonomi, berkenaan dengan masih pada peranan sumber daya yang langka dan terbatas untuk memuaskan keinginan karena adanya kebutuhan yang mendesak umumnya pula merupakan kebutuhan yang tidak terbatas.

Usahatani ini sesungguhnya tidak sekedar hanya terbatas pada pengambilan hasil, melainkan benar-benar merupakan usaha produksi. Disini belangsung pendayagunaan tanah, investasi, tenaga kerja, manajemen, keberhasilan dalam pendayagunaan ini barulah akan mendatangkan hasil yang dapat diambil. Kualitas dan kuantitas hasil akan sangat tergantung pada pengelolaannya, apabila pengelolaan berlangsung baik sejak awal sampai pengambilan hasil dan pemeliharaan hasil, maka kualitas dan kuantitas akan sangat memuaskan produsen (kartasapoetra, A.G. 1998). Tujuan petani dalam berusahatani adalah mendapatkan keuntungan sebesar-besarnya dari pilihan penggunaan faktor produksi (Hernanto, F. 1989). Pada suatu pertanian, pemimpin pertanian mengkombinasikan faktor-faktor produksi (Bishop, C.E. dan W.D. Toussaint, 1979).

Tujuan umum dari penelitian ini adalah menganalisis efisiensi ekonomi bawang putih di Kabupaten Karanganyar dan secara spesifik untuk mengkaji faktor-faktor produksi yang digunakan terhadap hasil produksi bawang putih yang ada di Kabupaten Karanganyar

\section{STUDI PUSTAKA}

Bawang putih merupakan tanaman yang berasal dari daerah sub tropis, sehingga di Indonesia daerah pengembangan tanaman ini pada umumnya didataran tinggi yang berhawa sejuk (Rukmana R, 1995). Bawang putih diushakan di lahan kering di ata 800 meter diatas permukaan laut. Adapn syarat tumbuh tanaman bawang putih dataran tinggi adalah sebagai berikut dengan suhu udara $15^{\circ}-20^{\circ}$ C. Kelembapan udara $60 \%$ - 80\% dan cukup mendapatkan sinar matahari.

Umbi bawang putih banyak mengandung zat-zat penting yang bermanfaat bagi kesehatan manusia. Zat antibiotika seperti germanium dan selenium yang terkandung dalam umbi bawang putih tergolong mineral antikanker yang ampuh dan dapat menghambat atau memusnahkan sel-sel kanker. Umbi bawang putih juga memiliki kandungan zat gizi yang terdiri protein, lemak, karbohidrat dan beberapa kandungan zat hara seperti kalsium, kalium dan vitamin (Samadi B., 2000).

Menurut Bachtiar dalam Fadholi Hernanto (1989), bahwa usahatani sebagai organisasi dari alam, kerja dan modal yang ditujukan kepada produksi lapangan pertaian. Pertania adalah suatu perusahaan yang khusus mengkombinasikan 
sumber-sumber dalam mengasilkan hasil-hasil (produksi) pertanian. (Bishop, CE dann W.D. Toussaint, 1979).

Bawang putih adalah umbi-umbian dengan nama latin Allium sativum. Bawang berwarna putih ini masih termasuk dalam keluarga tanaman amarilis (Amaryllidaceae), dan bersaudara dengan daun bawang dan bawang merah. Berambang putih adalah umbi siung asli budidaya Asia Tengah, tapi juga tumbuh liat di Italia dan daerah selatan Perancis.

Dalam satu buah bawang putih biasanya terdapat 1-10 siung. Setiap siungnya itu sendiri memiliki berat sekitar 6-8 gram. Maka, per 100 gram berambang putih kira-kira mengandung: 4 kalori, 1 gram karbohidrat, 0,2 gram protein, 0,1 gram serat, 0,1 miligram mangan (setara dengan 3\% kebutuhan harian tubuh), 0,9 miligram vitamin C (setara dengan 2\% kebutuhan harian tubuh), 5,4 miligram kalsium (setara dengan 1\% kebutuhan harian tubuh), 0,4 mikrogram selenium (setara 1 persen\% kebutuhan harian tubuh) dan sederet antioksidan seperti flavonoid, oligosakarida, dan asam amino (Joseph, 2020).

Bawang putih juga diperkaya oleh senyawa sulfur aktif seperti alliin, allyl propyl disulfide, dialil disulfida, dan dialil trisulfida. Ketika bawang putih mentah dikunyah dalam mulut, zat-zat sulfur tersebut akan bereaksi membentuk allicin yang membuat bawang putih mentah terasa getir atau angur (Imai, 2006).

\section{METODOLOGI PENELITIAN}

Metode dasar yang digunakan dalam penelitian ini adalah deskripif analitis, dengan ciri-ciri yaitu:

1. Memusatkan diri pada pemecahan-pemecahan masalah yang ada pada masa sekarang, pada masalah-masalah yag aktual.

2. Data yang dikumpulkan mula-mula disusun, dijelaskan dan kemudia dianalisa.

Untuk menganalisis suatu data, diperlukan satu cara berpikir, cara pengupasan, dengan referensi atau titik tolak tertentu untuk penampungan dan sintesa. Sedangkan teknik pelaksanaan penelitian dilakukan dengan menggunakan teknik survey yaitu cara pengumpulan data dari sejumlah unit atau individu dalam waktu yang bersamaan (Surakhmad, 1998). Selain itu dengan mengumpulkan data baik dari buku dokumen, jurnal internasional dan nasional, tesis, artikel prosiding, dan situs web yang berkaitan dengan objek penelitian kemudian dianalisis dengan teknik analisis teks (Wardhana, 2020).

\section{HASIL DAN PEMBAHASAN}

Dari hasil analisi dapat dijelaskan bahwa faktor produksi yang digunakan petani terdiri dari luas lahan garapan, teaga kerja, benih, pupuk kandang, pupuk Urea, pupuk SP36 dan pupuk KCl secara bersama-sama menunjukkan pengaruh 
yang sangat nyata terhadap produksi bawang putih, hal ini terlihat dai $\mathrm{F}$ hitung $(8,08)$ lebih besar dari $\mathrm{F}$ tabel $(3,25)$ pada tingkat kepercayaan 95\%.

Untuk menguji ketepatan model digunakan koefisiensi determinasi $\left(R^{2}\right)$. Semakin tinggi koefisiensi determinasi yang diperoleh, menunjukkan semakin baik model yang digunakan. Dari analisi hasil diketahui besarnya koefisien determinasi sebessar 0,639. Hali ini dapat dijelaskna bahwa dalam hasil produksi yang digunakan, sedangkan 36,1\% dipengaruhi faktor lainnya.

Dilihat dari hasil uji standard koefisiensi regresi parsial menunjukkan urutan pengaruh faktor produksi diantara faktor produksi lainnya yang paling dominan terhadap produksi bawang putih yaitu luas lahan, benih, pupuk kandang, pupuk Urea, pupuk SP36, tenaga kerja dan pupuk $\mathrm{KCl}$.

Besarnya elastisitas produksi total yang ditunjukkan dari penjumlaha masing-masing kefiseinsi regresi (elastisitas produksi parsial) dari variabel bebas (faktor produksi) sebesar 0,547. Ini dapat dijelaskan bahwa setiap penambahan semua faktor produksi sebesar $1 \%$ secara bersama-sama akan menaikkan produksi sebesar 0,547\%. Karena elastisitas produksi total kurang dari satu, maka menunjukkan bahwa proses prosuksi bawang puih berada pada daerah kedua yaitu pada fase produksi denga kenaikan hasilyang semakin berkurang (decresing return to scale). Ini berarti bahwa petani melakukan kegiatan usahataninya berada pada daerah rasional.

Balitsa menekankan bahwa produktivitas saja tidak cukup, karena Indonesia juga harus bisa bersaing dalam hal kualitas. Lebih lanjut Ka Balitsa menyampaikan tantangan berikutnya adalah bagaimana menurunkan biaya produksi bawang putih dan bagaimana teknologi ini dapat diterapkan pada skala produksi yang cukup untuk pemenuhan kebutuhan nasional. Apabila teknologi ini dapat dikembangkan pada skala nasional, kebutuhan luas tanam dan luas panennya dapat ditekan. Ka Balitsa mengharapkan hasil penelitian ini menjadi bukti kinerja dan sumbangan Balitbangtan untuk memenuhi produksi nasional bawang putih dan memenuhi program Kementerian Pertanian menuju swasembada bawang putih. Penyebarluasan dan penerapan teknologi ini di petani dan pihak-pihak yang berperan menjadi penting agar program swasembada bawang putih dapat terlaksana. Dalam akhir sambutannya, Ka Balitsa menyatakan bahwa Balitsa akan terus bekerja dalam lingkup sinergi Balitbangtan. Dalam waktu dekat, Puslitbanghortikultura akan memberikan materi pembekalan kepada seluruh BPTP yang mempunyai sentra produksi bawang putih, agar BPTP dapat berperan dalam penerapan teknologi budidaya bawang putih yang direkomendasikan Balitsa ini. Selanjutnya. Balitbangtan akan terus melakukan upaya perbaikan teknologi untuk menjawab permasalahan produksi di lapangan.

\section{KESIMPULAN}

Faktor-faktor produksi yang meliputi luas lahan dan pupuk kandang berpengaruh nyata terhadap produksi bawang putih. Sedangkan untuk faktor 
produksi seperti tenaga kerja, benih, pupuk Urea, pupuk SP36 dan pupul KCl tidak berpengaruh nyata terhadap produksi bawang putih. Adapun faktor produksi yang paling berpengaruh diantara faktor produksi lainnya adalah luas lahan, benih kemudian pupuk kandang, pupuk Urea, pupuk SP36 dan pupuk $\mathrm{KCl}$ sudah tidak efisien. Dengan demikian di dalam kombinasi faktor produksi menunjukkan alokasi faktor-faktor produksi pada usahatani bawang putih belum mencapai optimal.

Untuk mencapai alokasi yang optimal dalam usahatani bawang putih, pada faktor produksi luas lahan, petani pemilik penggarap dapat mengupayakan dengan peningkatan atau penambahan luas lahan dengan cara penggabungan areal lahan antar petani pemilik penggarap. Untuk faktor-faktor produksi seperti benih, pupuk kandang, pupuk Urea, pupuk SP36 dan pupuk $\mathrm{KCl}$ dianjurkan untuk mengikuti rekomendasi yang ada. Sedangkan pada faktor produksi tenaga kerja, penggunaan tenaga kerjadianjurkan dikurangi dan waktu pengelolaan usahatani lebih baik dilakukan pada pagi atau sore hari agar lebih efisien.

\section{DAFTAR PUSTAKA}

Balitsa Litbang. 2 Oktober 2019. Panen Bawang Putih Varietas Tawangmangu Baru Yang Luar Biasa. Diakses pada 30 Juli 2020. http://balitsa.litbang.pertanian. go.id/ind/index.php/berita-terbaru/849-panen-bawang-putih- varietas tawangmangu-baru-yang-luar-biasa

Bishop, C.E. dan W.D Toussaint. 1969. Pengantar Analisis Ekonomi Pertanian. Mutiara: Jakarta.

Entang, S. 1989. Ekonomi Pertanian Indonesia: Masalah, Gagasan dan Strategi. Angkasa: Bandung.

Hernanto, F. 1988. Ilmu Usahatani. Penebar Swadaya: Jakarta.

Imai, Shinsuke, Kaori Akita, Muneaki Tomotake, and Hiroshi Sawada. 2006. Model

Studies on Precursor System Generating Blue Pigment in Onion and Garlic. J. Agric. Food Chem. 54 (3): 848-852.

Rukmana, R. 1995. Budidaya Bawang Putih. Penerbit Kanisius: Yogyakarta.

Samadi, B. 2000. Usahatani Bawang Putih. Penerbit Kanisius: Yogyakarta.

Santoso, H.B. 1998. Bawang Putih. Penerbit Kanisius: Jakarta

Setyanto, Ari. 1992. Optimasi Penggunaan Faktor-Faktor Produksi Pada Usahatani Bawang Putih di Kabupaten Karanganyar. Fakultas Pertanian. UNS Press: Surakarta.

Soekatarwi, A. Soeharjo, J.L. Dillon dan J.B. Hardaker. 1986. Ilmu Usahatani dan Penelitian untuk Pengembangan Petani Kecil. UI Press: Jakarta.

Soekatarwi. 1993. Prinsip Dasar Ekonomi Pertanian, Teori dan Aplikasi. PT> Raja Grafindo Persada: Jakarta. 
1994. Teori Ekonomi Produksi Dengan Pokok Bahasan Analisi Fungsi Cobb-Doughlas. Rajawali: Jakarta.

1999. Agribisnis, Teori dan Aplikasi. PT. Raja Grafindo Persada: Jakarta.

Surakhmad, W. 1998. Pengantar Penelitian Ilmiah: Dasar, Metode dan Teknik. Tarsito: Bandung.

Sunaryo, H. 1990. Pengantar Pengetahuan Dasar Hortikultura. Sinar Baru: Bandung.

Joseph, Novita. dr. Tania Savitri. 15 Juni 2020. 10 Manfaat Mengejutkan Makan Bawang Putih Mentah. Diakses pada 30 Juli 2020. hellosehat.com/hidupsehat/fakta-unik/manfaat-bawang-putih-mentah/

Kartasapoetra, A.G. 1988. Pengantar Ekonomi Pertanian. PT. Bina Aksara: Jakarta.

Wandyatmoko, J. 1992. Konsepsi Pengembangan Agroindustri Nasional Dalam Mengantisipasi Liberalitas Investasi dan Perdagangan Dunia Tahun 2020. Majalah Ilmiah Kopertis Wilayah VI Vol. V No. 9 Tahun 1996.

Wardhana, I.P., S., Leo Agung, Pratiwi, V.U.. 2020. Konsep Pendidikan Taman Siswa Sebagai Dasar Kebijakan Pendidikan Nasional Merdeka Belajar di Indonesia. Prosiding Seminar Nasional Pendidikan Implementasi Merdeka Belajar Berdasarkan Ajaran Tamansiswa, Universitas Sarjanawiyata Tamansiswa (Vol. 1, No. 1). 